\title{
Purpuric lesions in the large bowel
}

\section{CLINICAL PRESENTATION}

A 54-year-old woman presented with a 1-week history of a rash starting in her feet. This was associated with arthralgia and myalgia. Her bowel habit was initially unchanged; however, she developed bloody diarrhoea shortly after admission to the hospital. She had no constitutional symptoms. Her medical history included myocardial infarction, hypothyroidism and a pituitary cyst.

On examination, there was a widespread nonblanching rash affecting her legs, feet, trunk, arms and palmar creases (figure 1). She had no fever or signs of meningism. Her abdomen was soft and non-tender. Laboratory tests revealed raised inflammatory markers (WCC $19.1 \times 10^{9} / \mathrm{L}$ and $\mathrm{C}$ reactive protein $84 \mathrm{mg} / \mathrm{L}$ ). Lactate was normal $(1.1 \mathrm{mmol} / \mathrm{L})$. Haemoglobin was $167 \mathrm{~g} / \mathrm{L}$; platelet count and coagulation profile were normal. Renal function and a vasculitis screen were unremarkable. Stool cultures were negative. Urine dipstick was negative for protein.

A CT scan of the abdomen revealed extensive inflammation extending from the distal ileum to the distal transverse colon. Flexible sigmoidoscopy showed purpuric lesions and patchy colitis (figure 2). Biopsy of the rash demonstrated acute perivascular inflammation and red cell extravasation (figure 3A,B). Biopsies of the large bowel showed focal cryptitis and an acute neutrophilic inflammatory infiltrate within the lamina propria (figure 3C,D).

\section{QUESTION}

What is the diagnosis? How would you treat it?

\section{ANSWER}

Histological description of skin biopsies is consistent with leucocytoclastic vasculitis, which is diagnostic of IgA vasculitis (formerly known as Henoch-Schönlein

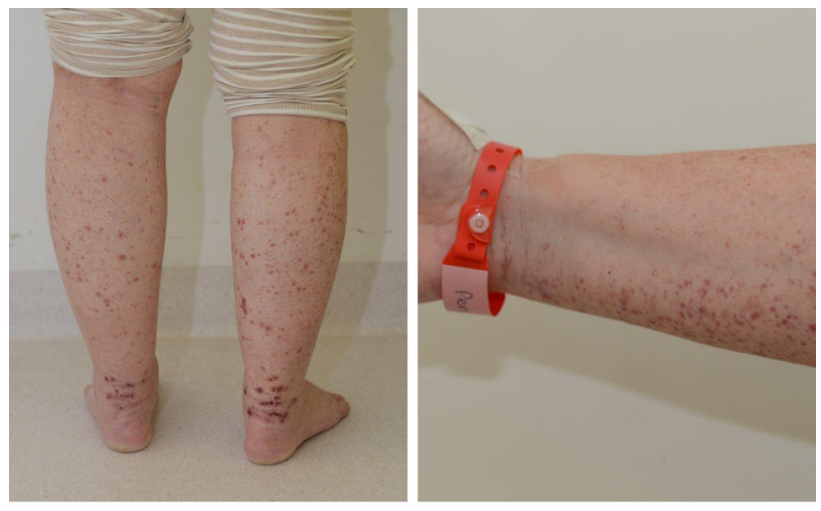

Figure 1 Medical photography of purpuric rash affecting the limbs.
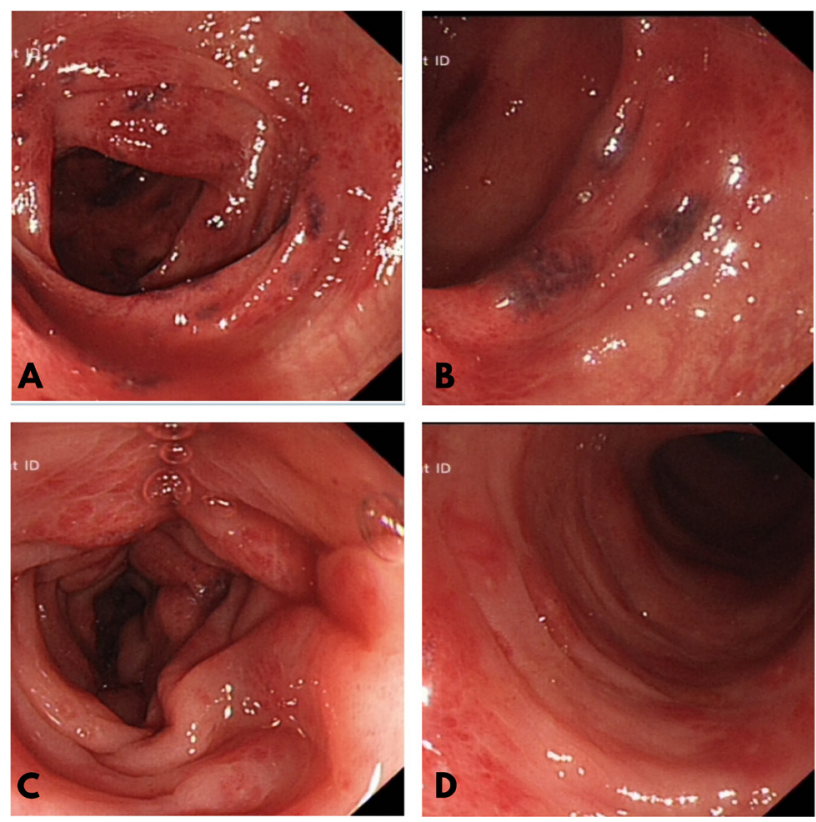

Figure 2 (A) Endoscopic view of the splenic flexure. (B) Endoscopic close-up view of the purpuric lesions in the splenic flexure. (C) Endoscopic view of patchy colitis in the distal descending colon. (D) Endoscopic view of patchy colitis in the proximal sigmoid colon.

purpura) in the right clinical context. European League Against Rheumatism (EULAR) 2010 revised criteria ${ }^{1}$ for IgA vasculitis requires the mandatory presence of purpura and one of the following four: abdominal pain, supporting histopathology, arthralgia/arthritis
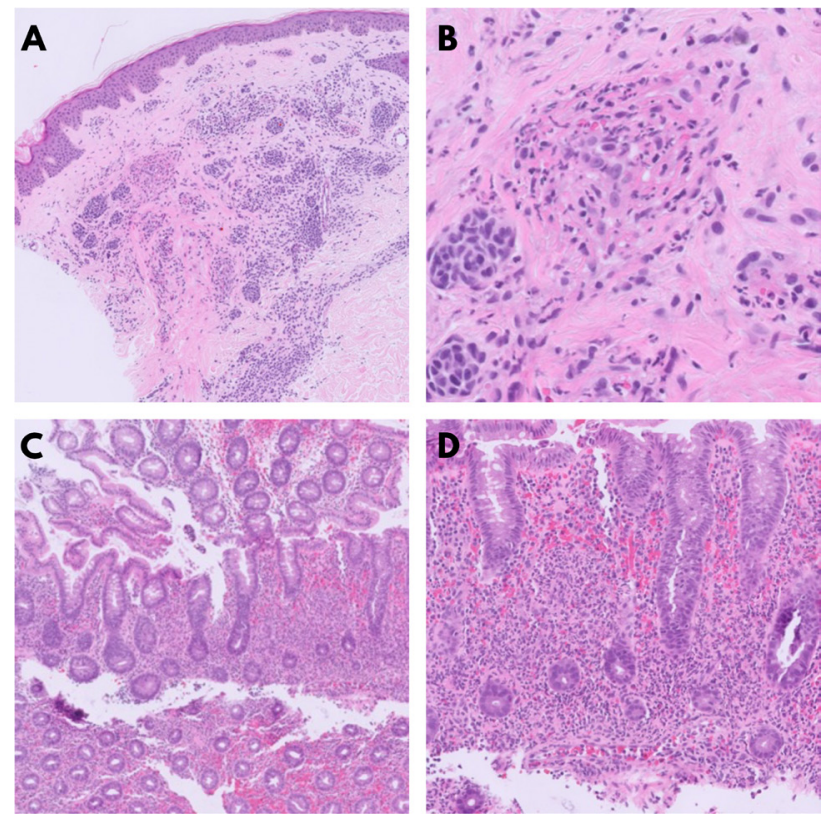

Figure 3 (A) Histological examination of skin biopsy showing perivascular dermal inflammation admixed with an intradermal naevus. (B) Skin histology showing perivascular inflammation and fibrinoid necrosis of a vessel wall. (C) Colonic mucosa specimen showing acute inflammation and withered crypts within the lamina propria. (D) Acute neutrophilic inflammation with red cell extravasation in the lamina propria. 
and renal involvement. IgA vasculitis is the most common type of vasculitis and usually affects children; however, it is more severe in adults. ${ }^{2}$

Gastrointestinal manifestations are seen in 50\%-75\% of patients, including diffuse abdominal pain, vomiting and rectal bleeding. ${ }^{3}$ Biopsy helps confirm the diagnosis, but negative biopsy does not exclude the disease. ${ }^{4}$ EULAR guidelines $2019^{5}$ on IgA vasculitis recommend considering corticosteroids in severe gastrointestinal symptoms; however, the evidence is limited to case series. Recommended doses are $1-2 \mathrm{mg} / \mathrm{kg} / \mathrm{day}$ for oral prednisolone and $10-30 \mathrm{mg} / \mathrm{kg}$ for pulsed IV methylprednisolone, depending on severity. Our patient received intravenous hydrocortisone before the diagnosis was clear and completed reducing prednisolone course with excellent clinical recovery. Differentiating IgA vasculitis from other causes of acute bloody diarrhoea such as inflammatory bowel disease has longterm implications. We highlight the clinical features of the disease with gastrointestinal involvement and advocate endoscopic examination in hospitalised patients.

\section{Giorgi Kiladze $\odot,{ }^{1}$ Ruby Cannan, ${ }^{1}$ David McClements, ${ }^{1}$ Richard George Brice ${ }^{2}$}

${ }^{1}$ Gastroenterology, St Helens and Knowsley Teaching Hospitals NHS Trust, Prescot, UK

${ }^{2}$ Histopathology, St Helens and Knowsley Teaching Hospitals NHS Trust, Prescot, UK

Correspondence to Dr Giorgi Kiladze, Gastroenterology, St Helens and Knowsley Teaching Hospitals NHS Trust, Prescot L35 5DR, UK; giorgikiladze@ doctors.org.uk

Contributors GK collected data, produced answer/discussion section of the manuscript, prepared figures 1 and 2 , edited the manuscript and approved the final version. $\mathrm{RC}$ collected data, produced question/clinical presentation section of the manuscript, approved the final version. DM planned the project, revised and edited the manuscript and approved the final version. RGB prepared the histology slides and corresponding figure 3 , provided commentary, edited the manuscript and approved the final version.

Funding The authors have not declared a specific grant for this research from any funding agency in the public, commercial or not-for-profit sectors.

Competing interests None declared.

Patient consent for publication Consent obtained directly from patient(s)
Provenance and peer review Not commissioned; externally peer reviewed.

\section{0 OPEN ACCESS}

Open access This is an open access article distributed in accordance with the Creative Commons Attribution Non Commercial (CC BY-NC 4.0) license, which permits others to distribute, remix, adapt, build upon this work noncommercially, and license their derivative works on different terms, provided the original work is properly cited, appropriate credit is given, any changes made indicated, and the use is noncommercial. See: http://creativecommons.org/licenses/by-nc/4. $0 /$

(C) Author(s) (or their employer(s)) 2022. Re-use permitted under CC BY-NC. No commercial re-use. See rights and permissions. Published by BMJ.

\section{Check for updates}

To cite Kiladze G, Cannan R, McClements D, et al. Frontline Gastroenterology Epub ahead of print: [please include Day Month Year]. doi:10.1136/ flgastro-2021-102055

Received 17 November 2021

Accepted 7 February 2022

Frontline Gastroenterology 2022;0:1-2. doi:10.1136/flgastro-2021-102055

ORCID iD

Giorgi Kiladze http://orcid.org/0000-0001-7038-1636

\section{REFERENCES}

1 Ozen S, Pistorio A, Iusan SM, et al. EULAR/PRINTO/PRES criteria for Henoch-Schönlein purpura, childhood polyarteritis nodosa, childhood Wegener granulomatosis and childhood Takayasu arteritis: Ankara 2008. Part II: final classification criteria. Ann Rheum Dis 2010;69:798-806.

2 Van de Perre E, Jones RB, Jayne DRW. Iga vasculitis (HenochSchönlein purpura): refractory and relapsing disease course in the adult population. Clin Kidney J 2021;14:1953-60.

3 Prathiba Rajalakshmi P, Srinivasan K. Gastrointestinal manifestations of Henoch-Schonlein purpura: a report of two cases. World J Radiol 2015;7:66-9.

4 Larson AR, Granter SR. Utility of immunofluorescence testing for vascular IgA in adult patients with leukocytoclastic vasculitis. Am J Clin Pathol 2014;142:370-4.

5 Ozen S, Marks SD, Brogan P, et al. European consensusbased recommendations for diagnosis and treatment of immunoglobulin A vasculitis-the share initiative. Rheumatology 2019;58:1607-16. 